\title{
Improvement Of Method Of Setting Digital Protection Devices In Straight DC Power Networks
}

\author{
B.V. Malozyomov \\ Novosibirsk State Technical University \\ Novosibirsk, Russian Federation \\ mbv5@mail.ru
}

M.V. Rozhkova

Novosibirsk State Technical University

Novosibirsk, Russian Federation

marina.rozhkova.63@mail.ru

\begin{abstract}
The paper describes methods for setpoints setting of digital protections (terminals) in traction DC networks. A technique for their improvement and protection settings in a complete scheme is proposed. Besides, the main technical characteristics of digital protection and automation devices are listed. Numerous network parameters, which include those affecting its service reliability, are also reviewed. The parameter factor evaluation of dc traction network servicing, including the random parameter affects, is given. The algorithm and the design procedure of the dc traction network are reported in the paper. Besides, a real operation circuit of traction network protection at the experimental site is considered.
\end{abstract}

Keywords - digital protection, method of protection settings, traction network, electric current

\section{INTRODUCTION}

In the last decade, several world companies have been producing digital automation, control and protection devices for traction network feeders - intelligent terminals (hereinafter referred to as "terminal") for ground and underground types of electric transport (Table 1), which design and assembly firms use in new projects and during modernization TP $[1,2]$. The devices of Table 1 are intended for performing the functions of relay protection of the railway feeders (RF) of direct current $3.3 \mathrm{kV}, 1.5 \mathrm{kV}, 825 \mathrm{~V}, 750 \mathrm{~V}$ and $600 \mathrm{~V}$, as well as control functions, emergency control, measurement, control and signaling, local and remote control switching devices. The block diagram of the digital terminal is shown in Fig. 1. Table 1 lists the parameters of digital protection of feeder automatic equipment, a new version of In-Tel manufactured in Russia, which was introduced at Russian Railways. For comparison, Table 1 lists the parameters of digital devices of well-known foreign firms [1-4].

\section{THEORY}

In the digital terminal, voltage and current measurement is performed by means of a resistive voltage divider and a shunt, the analog signal from which is fed to a buffer amplifier of direct current, where it is digitized and transmitted through a fiber optic cable providing high-voltage isolation to a digital

\author{
A.A. Shtang \\ Novosibirsk State Technical University \\ Novosibirsk, Russian Federation \\ shtang@corp.nstu.ru
}

protection and control unit (Fig. 1). In the digital unit, the logic controller monitors the signals from the sensors at $25 \mu \mathrm{s}-$ $2 \mathrm{~ms}$ intervals and compares them with the settings. The current increment $\Delta \mathrm{i}$ is defined as the difference between two adjacent measurements.

There are no clear settings for the selection of the protection status and their settings in [5]; only the possibility of solving these problems by experimental means is indicated. Thus, the three tasks formulated above, together with a number of external factors (for example, network parameters, the need to skip overweight trains, and others) can now be considered as a problem of ensuring the proper functioning of protections using innovative devices (intelligent terminals), which, according to the data Operational organizations are currently working mainly in the "signal" mode. To increase the reliability of the protection function, the authors propose the following procedure for selecting the types of protection in accordance with [6] (determining the protection status) and the method for calculating the settings using simulation, monitoring and verification of the security of the traction network. The choice of the protection settings is based on the comparison of the parameters of the normal mode with the maximum loads and the steady-state short circuit at the given point of the traction network. The choice is based on regulatory requirements to ensure the requirements for the stability of short-circuit protection. For selective protection, these conditions are:

a) sensitivity to short circuits within the protected area (internal short circuits);

b) detachment from the normal operation of the protected connection;

c) detuning from short circuits outside the protected zone (external short circuits).

For non-selective defenses, condition (c) is not presented for protection. In this case, it is required to provide correction of non-selective protection actions by means of automatic reclosing (ARC) [6].

When calculating the short-circuit parameters for each type of protection, depending on the place of its installation, the 
following parameters (required for use in calculations) are: power supply circuit of the substation zone and the fault location of the contact network, mode (maximum or minimum), damage location parameters and regulatory values of the coefficients ensuring the requirements of the stability of the protection function.

The composition of the protection of each of the switches must ensure the requirements for the stability of operation (points a) and b)). The sensitivity to short circuits of main and standby protections when selecting their settings is to be evaluated according to the sensitivity factor, hr.

The method of selecting settings for traditional protection, based on the maximum impulse protection of current (MIPc), includes the following main sections:

- analysis of the parameters of the power supply section of the traction network;

- choice of design schemes for normal, forced and emergency modes;

- creation of the database necessary for calculating the load currents and short-circuit currents;

- execution of calculations using the software complex "Kortes", or by other analytical means with high accuracy;

- selection of the type and zones of operation of the primary protection, identification of the possibilities of standby protections; card;

- verification of the functioning and security of traction network sections.

The method of selecting settings for digital protections (terminals) is based on the traditional method, but with the new capabilities of the digital terminal: a fundamentally new method for determining the magnitude of the current increments, which allows one to separately realize the functions of the maximum impulse protection of digital protection (MIPd), current cut-off (CC) and overcurrent protection $(\mathrm{OCP})$, performing the last digital protection as a bi-directional protection. One can use the rate of current rise $d i / d t$ and current increment $\Delta I$ in time $t$ as additional protections. For example, remote $(U / R)$ or current increments $\Delta I$ for time $t$, telelocking thermal protection, can be used as backup.

The method of choosing the settings of the digital terminal includes all the sections outlined above in the traditional method, while for the terminals it is necessary to additionally execute:

- Selection of types of main, backup and additional protection;

- Calculation of protection settings, filling in the settings

\section{BLOCK DIAGRAM}
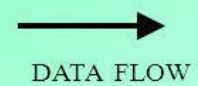

CONTROLFLOW

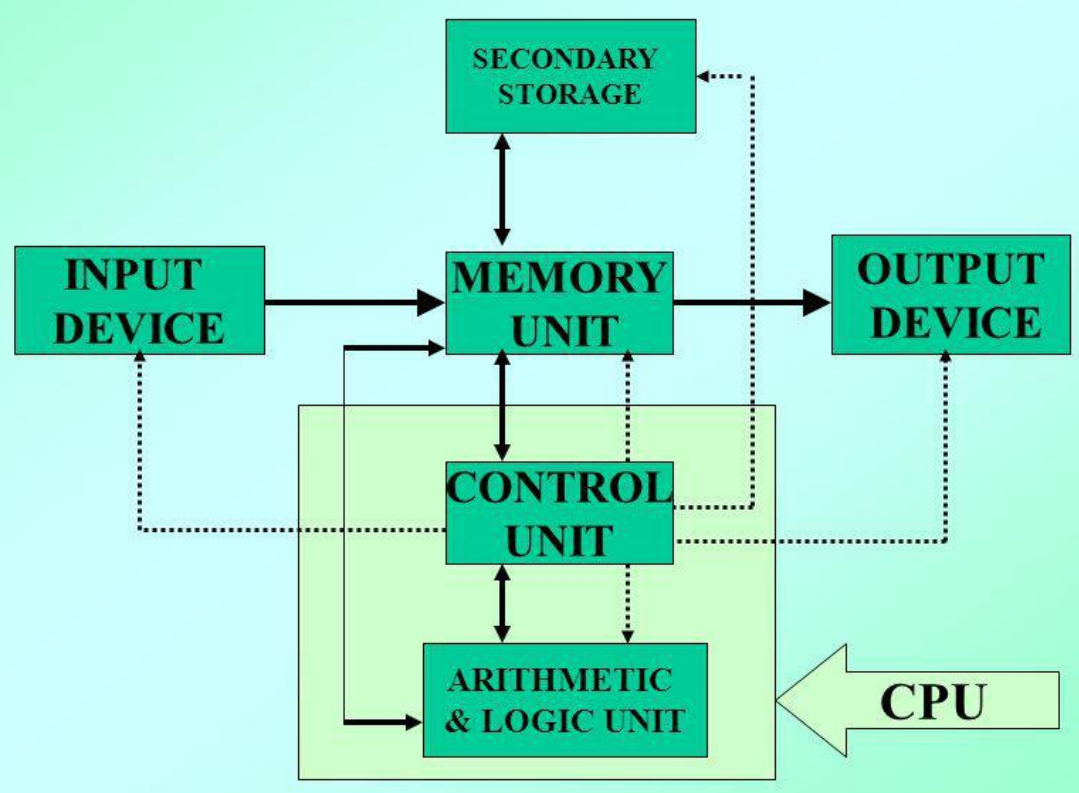

Fig. 1. The block diagram of the control and protection device of the Sepcos-ng type 
TABLE I. THE MAIN TECHNICAL CHARACTERISTICS OF DIGITAL PROTECTION AND AUTOMATION DEVICES

\begin{tabular}{|c|c|c|c|c|c|}
\hline \multirow[b]{2}{*}{ № } & \multirow[b]{2}{*}{$\begin{array}{l}\text { Basic blocks or } \\
\text { parameters }\end{array}$} & \multicolumn{4}{|c|}{ Name of the manufacturer } \\
\hline & & $\begin{array}{c}L L C \\
\text { «IIEFA-Energo» } \\
\text { Russia } \\
\end{array}$ & $\begin{array}{c}\text { CJSC } \\
\text { «SIEMENS» } \\
\text { Germany } \\
\end{array}$ & $\begin{array}{c}\text { CJSC } \\
\text { «SECHERON" } \\
\text { Switzerland } \\
\end{array}$ & $\begin{array}{c}\text { CJSC } \\
\text { «PLUTON" } \\
\text { Ukraine } \\
\end{array}$ \\
\hline 1 & Device type & In-tel & sitras pro & sepcors ng & SMTN 2 \\
\hline 2 & $\begin{array}{l}\text { Digital Protection and } \\
\text { Control Unit }\end{array}$ & Intelligent terminal (In-Tel) & $\begin{array}{l}\text { Logic controller } \\
\text { sitras pro cu }\end{array}$ & $\begin{array}{l}\text { Logic controller } \\
\text { (IES1131-3) }\end{array}$ & $\begin{array}{l}\text { Logic controller } \\
\text { (IEC1131-3) }\end{array}$ \\
\hline 3 & Current probe & $\begin{array}{l}\text { Shunt } 75 \text { shs, } 3000 \mathrm{~A} \text { or } \\
\text { Hall sensor }\end{array}$ & $\begin{array}{l}\text { Shunt } 60 \text { shs, } 3000 \mathrm{~A} \text { or } \\
\text { Hall sensor }\end{array}$ & $\begin{array}{l}\text { Shunt } 60 \text { shs, } 3000 \mathrm{~A} \text { or } \\
\text { Hall sensor }\end{array}$ & Shunt 75 shs,5000A \\
\hline 4 & Current voltage & Resistive divider & Resistive divider & Resistive divider & Resistive divider \\
\hline 5 & Isolating amplifier DC & electronic & electronic, sitras pro & electronic & electronic \\
\hline 6 & Control panel & $\begin{array}{l}\text { (control unit) } \\
\text { microprocessor, LEDs, } \\
\text { Monitor }\end{array}$ & $\begin{array}{c}\text { sitras pro hmi, 32-bit } \\
\text { microprocessor system, } \\
\text { monitor }\end{array}$ & $\begin{array}{l}\text { Multiple microprocessors, } \\
\text { LEDs, monitor }\end{array}$ & $\begin{array}{l}\text { Microprocessor, LEDs, } \\
\text { monitor }\end{array}$ \\
\hline 7 & The software of the user PC & modbus & sitras pro sw & ethernet & ethernet \\
\hline 8 & $\begin{array}{l}\text { Discreteness of current and } \\
\text { voltage measurement of } \\
\text { traction network }\end{array}$ & In $2 \mathrm{~ms}$ & In $2 \mathrm{~ms}$ & In $25 \mathrm{mcs}$ & In $2 \mathrm{~ms}$ \\
\hline 9 & $\begin{array}{l}\text { Monitoring of rectified } \\
\text { current feeder cables }\end{array}$ & no & sitras pro $\mathrm{cm}$ & yes & yes \\
\hline 10 & high voltage & fiber optic cable & fiber optic cable & fiber optic cable & fiber optic cable \\
\hline 11 & Functions of protection & $\begin{array}{l}\text { current cutoff without time } \\
\text { delay } \\
\text { maximal pulse protection - } \\
\text { mpp or something } \\
\text {-bidirectional overcurrent } \\
\text { protection with time delay- } \\
\text { - current increment } \Delta \mathrm{I} \text { during } \\
\text { the time ty - spt;-; } \\
\text { - Directional distance } \\
\text { protection (DDP) (minimum } \\
\text { resistance protection);- } \\
\text {-influence of the set limit } \\
\text { value of the rate of current } \\
\text { rise (di / dt); } \\
\text { - thermal protection against } \\
\text { annealing of the contact wire } \\
\text { (current protection - q = f } \\
\text { (t)); } \\
\text { Voltage reduction below } \\
\text { the specified level, umin - } \\
\text { or excess of voltage umax - } \\
\text {; } \\
\text {-blocking from the } \\
\text { inclusion of instantaneous } \\
\text { circuit breaker (ICB) on a } \\
\text { sustainable } \\
\text { (line insulation control - } \\
\text { input from a separate } \\
\text { - Short circuit test (a separate } \\
\text { device). }\end{array}$ & $\begin{array}{l}\text { - the maximum current } \\
\text { protection-mcp or that; } \\
\text { - exceeding the preset } \\
\text { The maximum current rise } \\
\text { rate (di / dt); } \\
\text { - protection for current } \\
\text { surges } \Delta \mathrm{i}(\mathrm{t}) ; \\
\text { - } \mathrm{i}_{\text {umz }} \text { protection } \\
\text { (Independent protection } \\
\text { against the time of the } \\
\text { current flow); } \\
\text { - the voltage drop is lower } \\
\text { than the preset level: } \\
\mathrm{U}_{\text {min }} \text { - or overvoltage } \\
\text { Umax -; } \\
\text { - blocking from the } \\
\text { inclusion of a high-speed } \\
\text { switch to a stable switch } \\
\text { (checking the insulation of } \\
\text { the line); } \\
\text {-Heat protection }\end{array}$ & $\begin{array}{l}\text { - maximum current } \\
\text { protection - hscb (ids); } \\
\text { - protection during } \\
\text { current surges } \\
\text { Imax + } \Delta \text { imax - (the } \\
\text { maximum current as a } \\
\text { function of time); } \\
\text { - line testing device; } \\
\text { - detection of short } \\
\text { circuits (di / dt and } \Delta \mathrm{i}(\mathrm{t}) \text { ); } \\
\text { - overvoltage control; } \\
\text { - reduced feeder voltage; } \\
\text { - heat protection }\end{array}$ & $\begin{array}{l}\text { current cutoff without } \\
\text { time delay (maximum } \\
\text { pulse cutoff); } \\
\text {-maximum-current } \\
\text { protection with time } \\
\text { delay; } \\
\text { - exceeding the preset } \\
\text { limit value of the } \\
\text { current rise rate (di / } \\
\text { dt); } \\
\text {-thermal protection); } \\
\text { - voltage drop below } \\
\text { the set level -Umin - } \\
\text { or overvoltage Umax; } \\
\text { - blocking from the } \\
\text { inclusion of a quick- } \\
\text { action switch to a stable } \\
\text { fault (line insulation } \\
\text { check) }\end{array}$ \\
\hline 12 & Internal interface & $\mathrm{RS}-232, \mathrm{RS}-485$ & RS - 232, RS -485 & $\mathrm{RS}-232, \mathrm{RS}-485$ & $\mathrm{RS}-232, \mathrm{RS}-485$ \\
\hline 13 & $\begin{array}{l}\text { Communication interface } \\
\text { with external devices }\end{array}$ & modbus, ethernet & (hmi) sitras, proprofibus d & ethernet, tcp/ip & ethernet, modbus, rtu \\
\hline 13 & $\begin{array}{l}\text { Communication interface } \\
\text { with external devices }\end{array}$ & modbus, ethernet & (hmi) sitras, proprofibus d & ethernet, tcp/ip & ethernet, modbus, rtu \\
\hline
\end{tabular}

- Calculation of the settings for each type, for each possible calculation scheme.

- Drawing up a map of settings and zones of stable operation.
To do this, it is necessary to define the sensitivity zone and the "dead" zone on the protected area. The authors will show this by an example, creating an experimental plot of three traction substations (TSS) and two rolling stocks (RS). 


\section{OUTCOME OF EXPERIMENT}

To verify the methodology for selecting settings, calculations have been made for the section of the traction network of the railway with three adjacent substations, two sectioning stations, with real parameters of the traction network. Calculations are made in the "Cortez" package. The calculation algorithm includes the following procedures.

1. Definition. Parameters and location of objects (details in the "Cortez" Instruction).

2. Database for calculations in the "Cortez" package. To do this, it is necessary to create files with the parameters of the site for each type of equipment specified in item 1 . At the stage of preparation of calculations, the parameters can be presented in the form of a table.

3. Choice of calculation schemes in accordance with established parameters in [7]

4. Creating a simulation model of the site (Fig. 2).

5. Results of calculation of short-circuit currents under normal and forced power circuits.

6. Selection of basic and backup protection.

7. Calculation of the settings (in detail in [8]).

The content of the procedures is given below.
1. According to the proposed methodology, the following types of protection were selected:

For traditional protection on feeders F1 and F5, traditional MIP is chosen as the main one;

2. On F2 and F4 feeders, there are installed traditional MIPc and digital terminals CZAF-3,3, on which a complex of three protections is switched on : bi-directional protection of OCP, MIPd and differential protection (DP), with the main accepted MIPc. The settings are chosen by the digital function in contrast to MIPc on RDS-3000, where the choice of settings is made according to the characteristics of the relay (in [9], Fig. 2).

3. Verification of the reliability of the functioning and security of the sections of the traction network.

After calculating the settings at the experimental site, it is necessary to check the overlap of the "dead" protection zones. The "dead" protection zone is the length of the section of the contact system (CS) where the protection device cannot selectively distinguish the short-circuit currents (SCC) from the load currents. They also include a section of the CS, where only one protection covers incompletely the length of the action, for example, half of the length. "Dead" zones are at remote points of the site of the CS.

TSS-

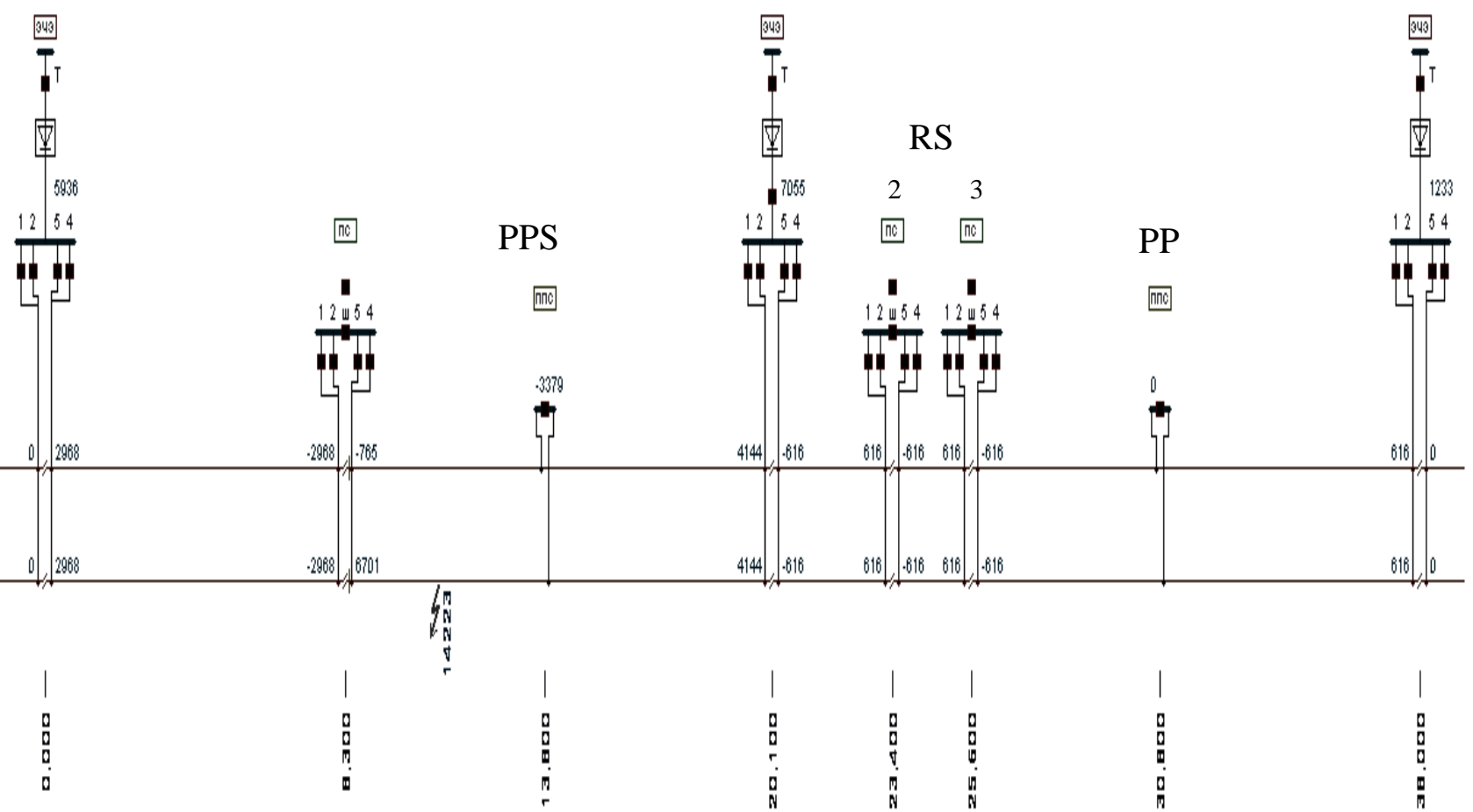

Fig.2. Simulation model of experimental site 
TABLE II. SHORT-CIRCUIT CURRENTS UNDER NORMAL AND FORCED POWER CIRCUITS

\begin{tabular}{|c|c|c|c|c|c|c|}
\hline \multirow{3}{*}{ Place of short circuit } & \multicolumn{3}{|c|}{ Normal scheme } & \multicolumn{3}{|c|}{ Forced scheme } \\
\hline & \multirow{2}{*}{$\begin{array}{c}\text { short circuit } \\
\text { point, } A\end{array}$} & \multicolumn{2}{|c|}{ Remote points } & \multirow{2}{*}{$\begin{array}{c}\text { short circuit } \\
\text { point, } A\end{array}$} & \multicolumn{2}{|c|}{ Remote points, $A$} \\
\hline & & Current, $A$ & place & & Current, $A$ & place \\
\hline On buses TSS -250 & 35557 & 4239 & RS-8 & 33495 & 1181 & TSS -252 \\
\hline RS -8 & 15911 & 3032 & TSS-252 & 11370 & 2685 & TSS -252 \\
\hline 10th-km, from TSS-250 & 14223 & 2995 & TSS -252 & 12984 & 3790 & TSS -252 \\
\hline PPS & 18238 & 2870 & RS -8 & 18211 & 2887 & TSS -250 \\
\hline On buses TSS -252 & 40706 & 1266 & RS -23 & 35484 & 1270 & TSS -250 \\
\hline On buses TSS -252 & 38718 & 3567 & RS -26 & 37535 & 1710 & TSS -241 \\
\hline$R S-23$ & 24285 & 9520 & RS -26 & 17886 & 1888 & TSS -241 \\
\hline$R S-26$ & 20663 & 3594 & TSS -241 & 15159 & 2367 & TSS -241 \\
\hline PPS & 19185 & 4174 & RS -26 & 19117 & 4168 & TSS -252 \\
\hline On buses TSS -241 & 36662 & 2692 & RS -26 & 32317 & 1597 & TSS -252 \\
\hline
\end{tabular}

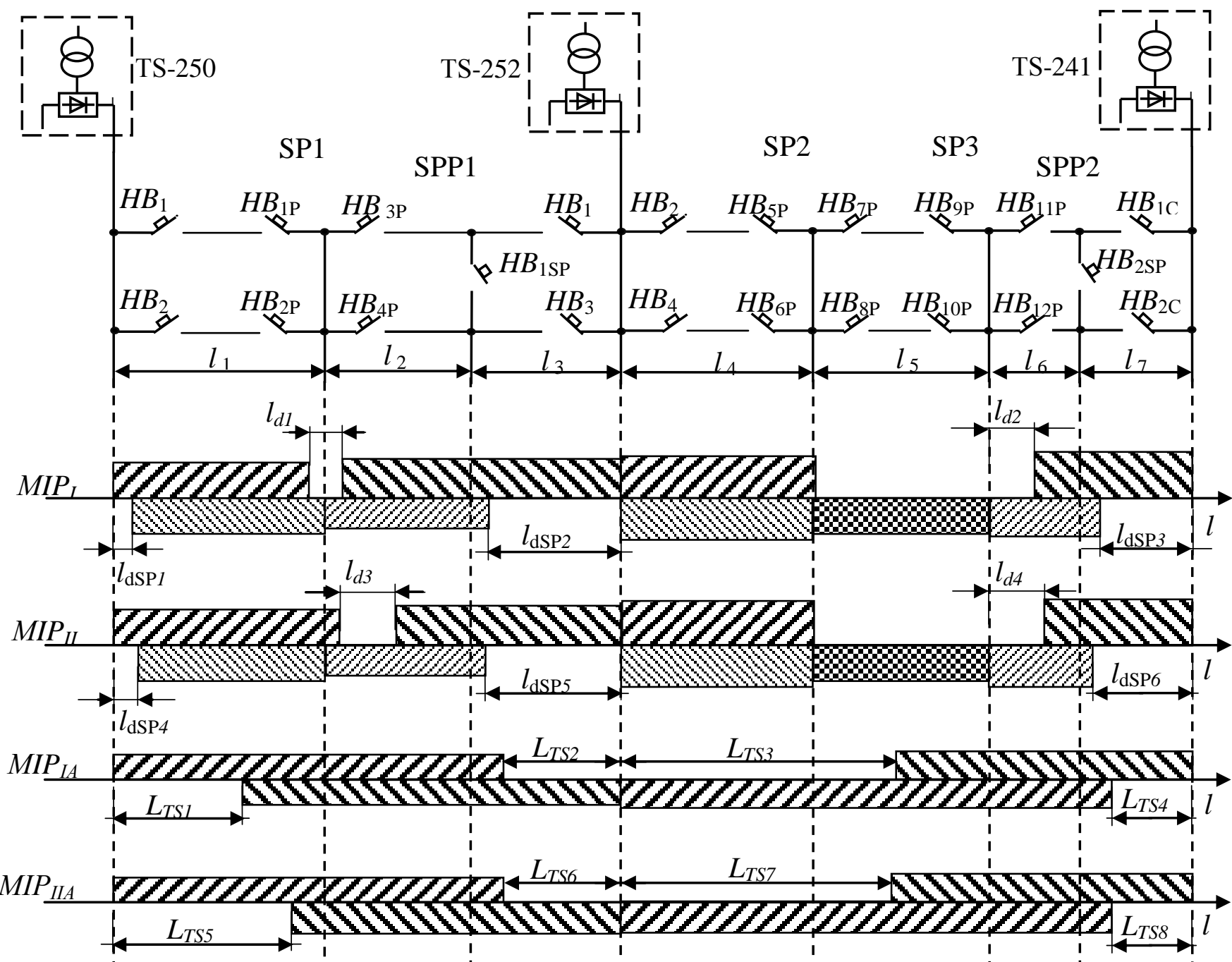

Fig. 3. MIP area from short-circuit currents at the examined section TS- TP 250-241: $\mathrm{MIP}_{\mathrm{I}^{-}}$-protection area for the first section, in the normal mode; $\mathrm{MIP}_{\mathrm{II}^{-}}$ protection area for the second section, in the normal mode; $\mathrm{MIP}_{\mathrm{IA}}$, $\mathrm{MIP}_{\mathrm{IA}}$-protection area for the first and second section, in the forced mode; $l_{d l} \div l_{d 4}-$ length of "dead" zones of protection in the normal mode; $l_{d S P I} \div l_{d S P \sigma}$-length of "dead" zones of sectioning points protection in the normal mode, partitioning $l_{T S I} \div l_{T S 6}-$ length of "dead" zones of TS protection in the forced mode

Figure 3 shows the power supply circuit of the pilot section and the protection zones of the MIP, installed on each switch of the transformer substation. In this case, RS-8, RS23, RS-26 cover "dead" areas of switches TSS-250, TSS-252,
TSS-241 with a normal power scheme. So, for example, "dead" zone LM3 of the protection device of instantaneous circuit-breaker (ICB) ICB3G TSS-252, overlaps the protection of ICB4P of RS-8. At the same time, if the ICB4P of RS-8 is 
disconnected due to SCC at this point, an emergency mode not sensitive to TSS protection will occur. Let us consider this case in more detail. With short circuit in zone 1M3, switch BV4P is switched off and power supply from the TP 250 is switched off. And from the TP-252 side, the BV3G switch will remain on. The protection in this zone is not sensitive, and eventually the fault will be fed to the remote point. In the forced mode, RS or PPS can be disabled. Then the coverage areas of the MIP with the settings, calculated for the normal mode, will not be able to block all inter-substation zones. For this purpose, the calculation for emergency modes was performed, according to the schemes of Table 4.1 in [10]. The lengths of the "dead" MIP zones for TP switches, in the normal operation mode of the vehicle, were LM1 $=1 \mathrm{~km}$; $\mathrm{LM} 2=0.5 \mathrm{~km} ; \mathrm{LM} 3=2.3 \mathrm{~km} ; \mathrm{LM} 4=0.5 \mathrm{~km}$. For PS breakers: $1 \mathrm{MP} 1=0.85 \mathrm{~km} ; \mathrm{LMP} 2=5.2 \mathrm{~km}$; LMP3 $=5 \mathrm{~km}$; LMP4 $=0.82 \mathrm{~km}$; LMP5 $=5.4 \mathrm{~km} ;$ LMP6 $=5.2 \mathrm{~km}$. For circuit breakers, in the forced mode of operation of the vehicle: $\mathrm{LMA} 1=5.6 \mathrm{~km} ; \mathrm{LMA} 2=4 \mathrm{~km} ; \mathrm{LMA} 3=4.6 \mathrm{~km}$; LMA4 $=4 \mathrm{~km} ;$ LMA5 $=7 \mathrm{~km} ;$ LMA6 $=4 \mathrm{~km} ;$ LMA7 $=4.1$ $\mathrm{km} ; \mathrm{LMA} 2=3.7 \mathrm{~km}$.

From the analysis of the work of the MIP, it follows that the use of only one type of protection leads to a large number of "dead" zones. At the same time, there is no full provision of protection for the MIP in the experimental section of the vehicle, which can lead to emergency consequences in case of short circuits.

\section{Checking the sensitivity of the protectors}

The sensitivity to short-circuits of the main and reserve protection when selecting their settings is to be evaluated according to the sensitivity factor (SF), the value of which, respectively, for the current (input influencing variable current), minimum voltage (input acting value - voltage) and remote (input influences - current and voltage) of protection are determined by [11].

\section{CONCLUSIONS}

Thus using only one type of protection leads to a large number of "dead" zones. Moreover, there is no full MIP for the TN section, which can lead to short-circuits accidental consequences. Adjusting protections settings, based on proposed methodology, reduces the length of "dead" zones by $20-25 \%$. Digital intelligent terminals should be used in conjunction with the MIP to ensure reliable operation of protection.

\section{References}

[1] B.A. Arzhannikov and A.A. Pyshkin, "Improving of DC power supply system based on automatic voltage regulation of traction substations (Sovershenstvovanie sistemi elektrosnabzheniya postoyannogo toka na osnove avtomaticheskogo regulirovaniya napryazheniya tyagovih podstanciy)", Ekaterinburg: "USURT Press", 2006, 116 p.

[2] B. Kroposki, R. Lasseter, T. Ise, S. Morozumi, S. Papathanassiou and N. Hatziargyriou, "A look at microgrid technologies and testing projects from around the world, making microgrids work", IEEE Power and Energy Magazine, Vol. 6, pp. 40-53, 2008

[3] E. Y. Abramov, N. I. Schurov and M. V. Rozhkova, "Electric transport traction power supply system with distributed energy sources", IOP Conference Series: Materials Science and Engineering, Vol. 127, 7 p , 2016.

[4] E.Y. Abramov, A.A. Stang and S.A. Enkudinov, "Transformation of the urban electric transport system when using autonomous energy sources", Advanced Materials Research, Vol. 1040, pp. 778-783, 2014

[5] V.I. Sopov, N.I. Schurov, Y.A. Prokushev and A.A. Shtang, "Increasing the efficiency of the use of electrical energy in the sub-subsystem of electric transport (Povishenie effektivnosti ispol'zovaniya elektricheskoy energii v subpodsisteme elektricheskogo transporta)", Improvement of technical means of electric transport (Sovershenstvovanie tehnicheskih sredstv elektricheskogo transporta), 2002, 189 p. [Digest of scientific works of the NSTU]

[6] V.ISopov, V.V. Biryukov, Y.A. Prokushev and Y.A. Rylov, "Analysis of power supply systems for rolling stock with various schemes of traction networks (Analiz sistem elektrosnabzheniya podvizhnogo sostava s razlichnimi shemami tyagovih setey)", Transport, Science, Engineering, Management (Transport, Nauka, Technika, Upravlenie). Vol. 2 (2008), pp. 49-53. [Digest of the VINITI RAS]

[7] V.V. Biryukov and A.V. Kulekina, "The calculation features of the electrical energy storage devices parameters in transport", The 11 International forum on strategic technology (IFOST 2016), pp. 41-43.

[8] N.I. Schurov, E.A. Spiridonov and A.V Larin, "Modes of traction power supply system in case of electric rolling stock equipped with energy storage", Applied Mechanics and Materials, Vol. 698, pp. 19-23, 2014.

[9] Photovoltaic (PV) research: National Renewable Energy Laboratory (NREL). Retrieved on http://www.nrel.gov/ncpv.

[10] N.W.A. Lidula and A.D. Rajapakse, "Microgrids research: a review of experimental microgrids and test systems", Renewable and Sustainable Energy Reviews, Vol. 15, pp. 186-202, 2011

[11] V.E. Rozenfeld, "Analytical calculation of electric railway networks (Analiticheskiy raschet setey elektricheskih zheleznih dorog)", The theoretical and scientific-practical peer-reviewed journal "Elektrichestvo", Vol. 9, pp. 6-17, 1947. 